\title{
Occurrence of Tetrodotoxin in Cultured Puffer
}

\author{
Sigeru Sato," Keiichi Komaru, ${ }^{*}$ Takehiko Ogata, ${ }^{*}$ \\ and Masaaki Kodama* \\ (Received January 5, 1990)
}

\begin{abstract}
A small amount of tetrodotoxin (TTX) was identified in the intestine of the cultured puffer Fugu rubripes specimens with ages of 60 days and 1 year old which are generally accepted to be nontoxic, whereas no toxin was detected in the liver. TTX-producing bacteria are reported to occur in the intestine of cultured $F$. rubripes as well as toxic wild one, suggesting that a low level of TTX in the intestine is produced by the intestinal TTX-producing bacteria. On the other hand, the absence of TTX in the liver indicates that puffer could not accumulate a low level of TTX which is maintained in the intestine for a long period.
\end{abstract}

Puffer often possess a potent neurotoxin, tetrodotoxin (TTX). Although there have been many efforts, little is known about the mechanism by which puffer are made toxic. On the other hand, it has been accepted informally among fish culturists that artificially hatched and cultured puffer Fugu rubripes are nontoxic, although the reason is not clear. F. rubripes is moderately toxic species. ${ }^{1)}$ Matsui et al. ${ }^{2)}$ confirmed this fact using strongly toxic species $F$. niphobles. They found that nontoxic cultured puffer become toxic when they are fed the diet containing TTX. ${ }^{3)}$ These findings suggest that TTX in puffer is exogenous and that puffer accumulate TTX through digestive organ.

Recently, Noguchi et al. ${ }^{4)}$ and Yasumoto et al. ${ }^{5)}$ have reported that TTX is produced by some bacteria. From this, they pointed out that the origin of TTX is these bacteria. More recently, Noguchi et al ${ }^{\circ)}$ have found these bacteria in the intestine of toxic specimens of several species of puffer and indicated that TTX accumulated in these puffer originates from the intestinal TTXproducing bacteria. However, they found later that bacterial flora in the intestine of nontoxic specimens of cultured puffer $F$. rubripes are similar to those of toxic wild ones. ${ }^{72}$ This findings suggest that cultured puffer also possess a low level of TTX which could not be detected by the standard method. ${ }^{8)}$ As a part of the study to elucidate the mechanism of TTX accumulation by puffer, TTX in the intestine and liver of cultured puffer $F$. rubripes with different ages was analyzed. We report here that a low level of
TTX occurs in the intestine of all the specimens of cultured puffer $F$, rubripes examined which are in different growth stages, while no TTX is detected in the liver in any case.

\section{Materials and Methods}

\section{Materials}

Fourteen specimens of 60 days old puffer $F$. rubripes were obtained from the Mariculture Center of Fukuoka Prefecture. Four specimens of 1 year old cultured $F$. rubripes were kindly supplied by Ehime Suisan Co. Ltd. Viscera taken out from the specimens were dissected into the liver and the intestine (digestive tract). The $100 \mathrm{~g}$ and $205 \mathrm{~g}$ of the liver, and $60 \mathrm{~g}$ and $315 \mathrm{~g}$ of the intestine were obtained from 60 days and 1 year old puffer, respectively.

\section{Extraction of the toxin}

Each organ was extracted with equal volume of $80 \%$ EtOH containing $1 \%$ acetic acid three times. Each extract was combined, evaporated to remove EtOH, defatted with dichloromethane and evaporated into dryness. The residue was dissolved in a known volume of water and injected into mice intraperitoneally. The toxicity was assumed from the time of death of mice using Kawabata's dosedeath time table for TTX and expressed as mouseunits (MU) where $1 \mathrm{MU}$ is a dose of TTX to kill a 20 -g male mouse ( $\mathrm{dd} Y$ ) in 30 min. $^{8)}$

\section{Partial purification and determination of the toxin}

Toxin in the crude extract was loaded to Bio-

* Laboratory of Marine Biological Chemistry, School of Fisheries Sciences, Kitasato University, Sanriku, Iwate 022-01, Japan (佐藤 繁，小丸圭一, 緒方武比古, 児玉正昭: 北里大学水麾学部水産物化学研究室). 
Gel P-2 column $(3.5 \times 40 \mathrm{~cm})$ prepared with newly purchased resin. The column was washed with water and the toxin adsorbed to Bio-Gel P-2 was eluted with $0.03 \mathrm{M}$ acetic acid. The toxin in the eluate was analyzed by mouse bioassay, mouse neuroblast cell culture bioassay ${ }^{0,10)}$ and HPLCfluorometric analysis. ${ }^{11)}$

\section{Results}

\section{Toxicity of organs}

The both extracts equivalent to $10 \mathrm{~g}$ of the intestine from 60 days and 1 year old puffer killed mice with similar signs to those of TTX or paralytic shellfish toxins. The toxicity was very low (about $0.2 \mathrm{MU} / \mathrm{g}$ of tissue as TTX). No significant difference was observed in the toxicity of the intestine extracts between 60 days and 1 year old puffer. In contrast, the identical doses of the liver extracts of 60 days and 1 year old specimens neither killed mice nor showed any signs of toxins, indicating that the toxicity of the liver was less than $0.1 \mathrm{MU} / \mathrm{g}$, if any.

\section{Partial purification and identification of the toxin}

A $57 \mathrm{MU}$ of the toxin from the intestine of 1 year old specimens was applied to a Bio-Gel P-2 column chromatography. Almost $100 \%$ of toxin was adsorbed to Bio-Gel P-2 and recovered by elution with $0.03 \mathrm{M}$ acetic acid. Toxin thus purified was freeze dried, dissolved in a small amount of water, and analyzed by an HPLCfluorometric analyzer of TTX. ${ }^{11}$ A peak with the same retention time as TTX appeared (Fig. 1). The Peak height of TTX was parallel to the toxicity of the extract calculated from mouse bioassay and mouse neuroblast cell culture bioassay ${ }^{8,10)}$ showing that cultured $F$. rubripes possess a low level of TTX in the intestine.

As described above, the extract of the liver did not show any toxicity in mouse bioassay. Thus, the liver extract of 1 year old puffer $(100 \mathrm{~g})$ was treated with a column of Bio-Gel P-2 as in the same manner described above. After washing the column with water, the substance adsorbed to Bio-Gel P-2 was eluted with $0.03 \mathrm{M}$ acetic acid. The eluate was concentrated to $2.5 \mathrm{ml}$. At the same time, $100 \mathrm{MU}$ of authentic TTX was added to the same volume of the liver extract and treated in the same manner. Extracts equivalent to $40 \mathrm{~g}$ and $2 \mathrm{~g}$ of the liver were assayed by mouse bioassay and cell culture bioassay, respectively. Extract equivalent to $2 \mathrm{~g}$ was also analyzed by


Fig. 1. HPLC of authentic TTXs (2.0 MU as TTX) (upper) and TTX fraction of the intestine of $F$. rubripes (2.1 MU as TTX) (lower). TA: tetrodonic acid, TTX: tetrodotoxin.

HPLC-fluorometric analysis. No toxin was detected in the liver extract in any analysis, whereas almost $100 \%$ recovery of added TTX was confirmed by the analyses. From this, the liver has no toxicity, or if any is less than $0.005 \mathrm{MU} / \mathrm{g}$.

\section{Discussion}

A low level of TTX (below $1 \mathrm{MU} / \mathrm{g}$ ) was detected in the intestine of all the specimens of cultured puffer $F$. rubripes, which were in different growth stages. No significant difference in the toxicity was observed among the specimens of 60 days and 12 months old. It has been generally accepted that cultured $F$. rubripes are nontoxic, though the reason is not clear. However, the results of the present study show that cultured $F$. rubripes possess TTX in the intestine, the level of which is too low to be detected by the standard method. ${ }^{8)}$ Recently, TTX was found to be produced by some bacteria. ${ }^{4, s}$ These TTX-producing bacteria are distributed widely in the environment. ${ }^{12)}$ Noguchi et $a l .{ }^{63}$ reported that TTXproducing bacteria belonging to the genus Vibrio such as $V$. alginolyticus are dominant in the in- 
testine of TTX-bearing animals including puffer. From this, they indicated that these intestinal TTX-producing bacteria are responsible for the TTX accumulation of puffer and other TTXbearing animals. However, they have found later that bacterial flora of cultured $F$. rubripes are very similar to those of the wild toxic one and that $V$. alginolyticus occurred also in the intestine of cultured specimens. ${ }^{72}$ These findings suggest that a low level of TTX in the intestine of cultured $F$. rubripes found in the present study is due to TTX-producing bacteria such as $V$. alginolyticus. Toxin production of TTX-producing bacteria such as $V$. alginolyticus in culture is reported to be very small.4-0,13,14) A low level of TTX in the intestine of cultured $F$. rubripes seemed to reflect the low TTX production of intestinal bacteria.

Interestingly, TTX was not detected in the liver of any specimen of cultured $F$. rubripes. This fact shows that puffer do not accumulate a low level of TTX in the liver through the digestive organ, in spite of having been keeping it for several months in the intestine. Matsui et $a l^{33}$ reported that the liver and skin of cultured $F$. rubripes become toxic when the fish are fed a diet containing TTX. This finding shows clearly that puffer absorb TTX in the diet through the digestive organ and accumulate it in the liver or other organs. Watabe et al. ${ }^{15}$ reported that tritiated TTX intraperitoneally administered to $F$. rubripes is accumulated in most of the tissues, especially highly in the skin and liver. With time, the accumulated TTX level in most of the organs decreased, but a high level was maintained in the skin. In contrast, the level in the gallbladder increased. These findings suggest that TTX highly accumulated in the liver moved to the skin and gallbladder from which TTX would be excreted to the environment. On the other hand, we have found that toxic puffer possess developed glands or cells in the skin which excrete TTX from the body. ${ }^{16)}$ These facts suggest that the amount of TTX accumulated in puffer is the difference between the amounts of the intake and excretion. If it is the case, the present results imply that the rate of excretion is higher than that of absorption because of low toxin contents in the intestine of cultured puffer. In other words, a low level of TTX in the intestine could not make the puffer liver toxic. If the high level of TTX in the liver of wild puffer is due to the intestinal bacteria, they should produce a remarkably high level of TTX in the intestine of wild puffer.

\section{Acknowledgment}

We are grateful to Mariculture Center of Fukuoka Prefecture and Ehime Suisan Co. Ltd for kind supply of puffer $F$. rubripes.

\section{References}

1) I. Tani: Toxicological Studies in Japanese Puffers, Teikoku Tosho, Tokyo, 1945, p. 103.

2) T. Matsui, H. Sato, S. Hamada, and C. Shimizu: Nippon Suisan Gakkaishi, 48, 253 (1982).

3) T. Matsui, S. Hamada, and S. Konosu: Nippon Suisan Gakkaishi, 47, 535-537 (1981).

4) T. Noguchi, J. Jeon, O. Arakawa, H. Sugita, Y. Deguchi, Y. Shida, and K. Hashimoto: $J$. Biochem., 99, 311-314 (1986).

5) T. Yasumoto, D. Yasumura, M. Yotsu, T. Michishita, A. Endo, and Y. Kotaki: Agric. Biol. Chem., 50, 793-795 (1986).

6) T. Noguchi, D. F. Hwang, O. Arakawa, H. Sugita, Y. Deguchi, Y. Shida, and K. Hashimoto: Marine Biology, 94, 625-630 (1987).

7) H. Sugita, T. Noguchi, M. Furuta, T. Harada, O. Murata, K. Hashimoto, and Y. Deguchi: Nippon Suisan Gakkaishi, 54, 733 (1988).

8) T. Kawabata: in "The Manual for the Methods of Food Sanitation Tests (Shokuhin Eisei Kensa Shishin) II", Japan Food Hygienic Association, Tokyo, 1978, pp. 232-240.

9) K. Kogure, M. L. Tamplin, U. Simidu, and R. R. Colwell: Toxicon, 26, 191-197 (1988).

10) S. Sato, T. Ogata, M. Kodama, and K. Kogure: in "Proccedings of Japanese Association of Mycotoxicology, IUPAC '88 and ICPP '88, Mycotoxins and Phycotoxins" (ed. by K. Aibara, S. Kumagai, K. Ohtsubo, and T. Yoshizawa), suppl. No. 1., the Japanese Association of Mycotoxicology, Tokyo, 1988, pp. 3-4

11) T. Yasumoto, and T. Michishita: Agric. Biol. Chem., 49, 3077-3080 (1985).

12) U. Simidu, T. Noguchi, D. F. Hwang, Y. Shida, and K. Hashimoto: Appl. Environ. Microbiol., 53, 1714-1715 (1987).

13) H. Narita, S. Matsubara, N. Miwa, S. Akahane, M. Murakami, T. Goto, M. Nara, T. Noguchi, T. Saito, Y. Shida, and K. Hashimoto: Nippon Siasan Gakkaishi, 53, 617-621 (1987).

14) A. Kungsuwan, T. Noguchi, O. Arakawa, U. Simidu, K. Tsukamoto, Y. Shida, and K. Hashimoto: Nippon Suisan Gakkaishi, 54, 17991802 (1988).

15) S. Watabe, Y. Sato, M. Nakaya, N. Nogawa, K. Oohashi, T. Noguchi, N. Morikawa, and K. Hashimoto: Toxicon, 25, 1283-1289 (1987).

16) M. Kodama, S. Sato, T. Ogata, Y. Suzuki, T. Kaneko and K. Aida: Toxicon, 24, 819-829 (1986). 